\title{
Riparian Wetlands of Tropical Streams
}

\author{
Karl M. Wantzen, Catherine M. Yule, Klement Tockner, and Wolfgang J. Junk
}

\author{
I. Introduction 199 \\ II. Types of Riparian Wetlands 201 \\ III. Hydrology 206 \\ IV. Biodiversity 208 \\ V. Aquatic-Terrestrial Linkages 209 \\ VI. Human Impacts, Conservation, and Sustainable Management 211 \\ VII. Conclusions and Prospects 212 \\ References 213
}

\begin{abstract}
Riparian wetlands are temporarily or permanently inundated and/or water-logged zones along the margins of streams and rivers. They link permanent aquatic habitats with upland terrestrial habitats, and surface-water with groundwater. This chapter focuses on riparian wetlands associated with low-order tropical streams, which have been lesser studied than equivalent ecotones associated with large rivers. We demonstrate that (a) these wetlands provide valuable habitats for diverse and highly specialized flora and fauna; (b) these serve as important longitudinal and transversal corridors for exchange of material and dispersal of biota; and (c) these perform important ecosystem functions locally as well as at the catchment scale. For example, headwater wetlands are key sites for mutual subsidies between terrestrial and aquatic systems, and are pivotal areas for the transformation of nutrients and organic matter. All riparian wetlands are subject to significant modification by humans, which compromises their functional integrity. However, riparian ecotones along loworder streams often occupy limited areas beyond the banks, and awareness of their ecological importance is limited in comparison to the extensive wetlands and floodplains associated with large lowland rivers. Creating awareness of the need for their sustainable management will be a challenging task.
\end{abstract}

\section{INTRODUCTION}

Riparian wetlands have been defined as 'lowland terrestrial ecotones which derive their high water tables and alluvial soils from drainage and erosion of adjacent uplands on the one side or from periodic flooding from the other' (McCormick, 1979). In contrast to an 'idealized river corridor', where vast riparian wetlands develop primarily along downstream sections, riparian wetlands associated with tropical headwater streams occur in a variety of forms, but mainly as floodplains of variable width. Like more extensive, larger ecotones associated with higher order rivers, riparian wetlands provide habitats for specific, diverse, and often endangered flora and fauna, and are thus fundamental to maintaining high biodiversity in and along streams (Naiman et al., 1998, 2005; see also Chapter 6 of this volume). Riparian wetlands are also responsible for multiple ecological functions: for instance, these serve as important hydrological buffers and key retention areas for sediments, agricultural pesticides, and fertilizers (Brinson, 1993; Tockner and Stanford, 2002; Naiman et al., 1998, 2005). These are sites of high primary and secondary 
productivity, and also act as migration corridors and/or microclimatic retreats for many taxa (Naiman et al., 2005). Several studies have emphasized the significance of riparian wetlands for stream organic-matter budgets (Wantzen and Junk, 2000), solute balance (McClain et al., 1994; McClain and Elsenbeer, 2001), and the structure of benthic invertebrate assemblages (Smock, 1994; Arscott et al., 2005).

We are relatively well informed about the structure and function of large floodplains, and recent reviews by Junk and Wantzen (2004) and Tockner and Stanford (2002) indicate the present state of our knowledge and offer a detailed synopsis, which we do not wish to repeat. Comprehensive accounts of the ecology of temperate riparian zones are given by Naiman et al. (2005) and Wantzen and Junk (in press). By contrast, our understanding of riparian wetlands along headwater streams in the tropics is still in its infancy. Accordingly, it is the ecology of these systems that we focus in this chapter. While headwater wetlands may not extend far beyond the stream channel, their importance becomes very evident from a calculation of their cumulative area within a catchment (Table I; see also Brinson, 1993; Tockner and Stanford, 2002). As Table I shows, the extent of floodplain associated with low-order streams can match or exceed that of large rivers. Unfortunately, these wetlands may not be considered or included in management or planning strategies. For example, 1:250000 scale maps employed in a landscape planning study in Mato Grosso (Brazil) omitted half of the first-order-streams in the catchment of interest, and thus no consideration was given to their associated wetlands (Wantzen et al., 2006).

There are several reasons for the paucity of information about riparian wetlands along low-order streams. Firstly, the investigation of these wetlands is laborious because they are integral components of a larger landscape, and are thus influenced by processes acting at a variety of scales in aquatic and terrestrial environments. Secondly, the processes acting within riparian wetlands may occur seasonally or intermittently with limited spatial extent. Their functional performance is, therefore, often wider appreciated, despite frequently incorporating important biogeochemical and metazoan-driven turnover processes, i.e. so-called 'hot spots' and 'hot moments' (sensu McClain et al., 2003; Wantzen and Junk, 2006). Thirdly, riparian wetlands of all types have been widely affected by sustained human impacts, such as conversion for agriculture, channelization, and flood-control structure, and these changes have already modified the structure and functional integrity of these ecotones. Fourthly, many wetlands and riparian zones in the tropics are unpleasant study sites that harbor poisonous snakes, stinging

TABLE I Stream Order, Estimated Number of Streams, Average and Total Length of Rivers and Streams, Average Riparian Width and Total Floodplain Surface Area in the USA

(Brinson, 1993; after Leopold et al., 1964)

\begin{tabular}{|c|c|c|c|c|c|}
\hline Stream order & Number & $\begin{array}{l}\text { Average length } \\
(\mathrm{km})\end{array}$ & $\begin{array}{l}\text { Total length } \\
(\mathrm{km})\end{array}$ & $\begin{array}{l}\text { Estimated } \\
\text { floodplain } \\
\text { width }(m)\end{array}$ & $\begin{array}{l}\text { Floodplain } \\
\text { surface area } \\
\left(\mathrm{km}^{2}\right)\end{array}$ \\
\hline 1 & $1,570,000$ & 1.6 & $2,526,130$ & 3 & 7,578 \\
\hline 2 & 350,000 & 3.7 & $1,295,245$ & 6 & 7,771 \\
\hline 3 & 80,000 & 8.5 & 682,216 & 12 & 8,187 \\
\hline 4 & 18,000 & 19.3 & 347,544 & 24 & 8,341 \\
\hline 5 & 4,200 & 45.1 & 189,218 & 48 & 9,082 \\
\hline 6 & 950 & 103.0 & 97,827 & 96 & 9,391 \\
\hline 7 & 200 & 236.5 & 47,305 & 192 & 9,082 \\
\hline 8 & 41 & 543.8 & 22,298 & 384 & 8,562 \\
\hline 9 & 8 & $1,250.2$ & 10,002 & 768 & 7,681 \\
\hline 10 & 1 & $2,896.2$ & 2,896 & 1536 & 4,449 \\
\hline
\end{tabular}


insects such as mosquitoes, and dense, thorny vegetation; when combined with their sometimes restricted spatial extent, these features help to account for the lack of attention headwater wetlands have received from researchers.

The term 'tropical', as used throughout this book, does not refer to a single set of conditions but can be subdivided into different regional landscapes and climatic types. This caveat is important especially for the present chapter since the inundation frequency and duration of riparian wetlands depends greatly on climate, which will, for example, differ between humid equatorial regions and seasonal monsoonal latitudes with distinct wet and dry seasons. In this chapter, we provide examples of headwater wetlands from different climatic areas including seasonal savannahs (Cerrado, Brazil), inland rainforests (Amazonia, Brazil), coastal lowland forests (peatswamp forest, Malaysia), and (sub)tropical Africa and Australia. Due to a wide range of wetland types, we first summarize the general features shared by riparian wetlands and then introduce some representative wetlands from different tropical regions. We conclude with recommendations for conservation and management of these habitats, and outline some priorities for future research.

\section{TYPES OF RIPARIAN WETLANDS}

The term 'wetland' is rather broad and includes a range of habitat types (see Tiner, 1999). It includes temporary wetlands along the margins of 'flashy', spate-prone streams as well as flood-pulsing wetlands arranged as 'pearls on a string' along river or steam corridors (Fig. 1; see also Ward et al., 2002; Wantzen, 2003; Junk and Wantzen, 2004). Permanent, moist wetlands are dominant in areas with high precipitation, low drainage, and shallow groundwater tables. In anastomosing river sections, these often consist of 'terrestrialized' meanders and anabranches. The extent of the connection of these wetlands with the stream channel during pulsed flow

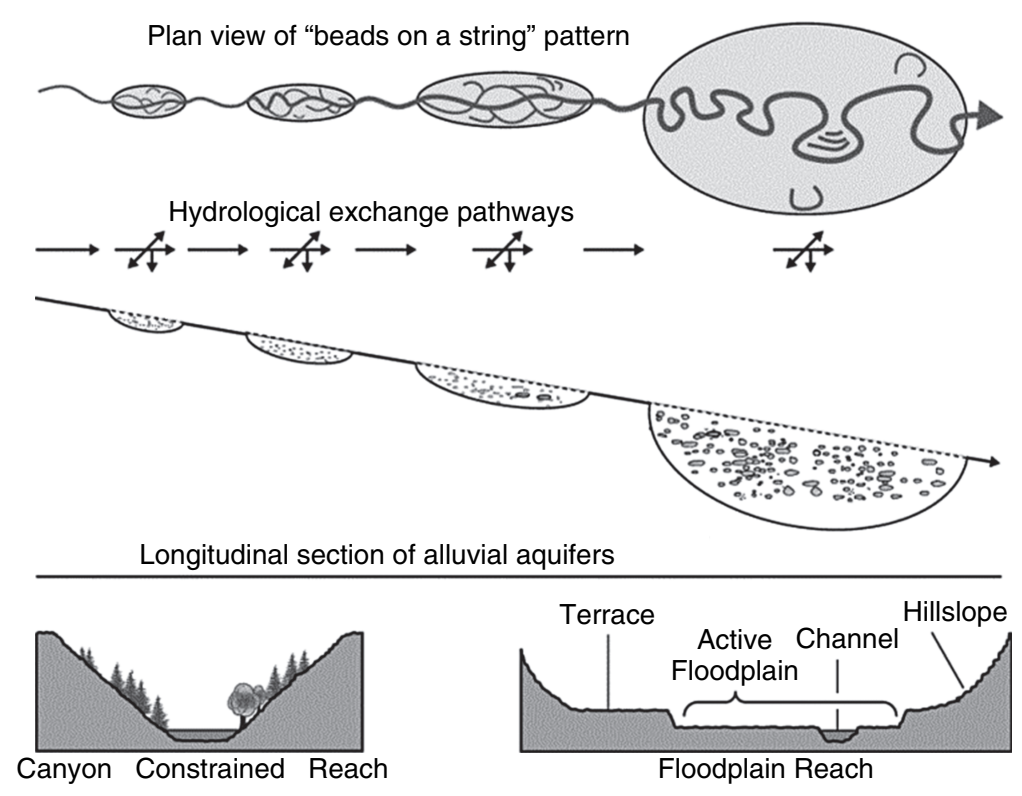

FIGURE 1 Idealized configuration of a river corridor as an alternating sequence of constrained reaches and floodplain sections. Predominant hydrological exchange pathways are indicated for longitudinal (horizontal arrows), lateral (oblique arrows), and vertical (vertical arrows) dimensions (after Ward et al., 2002; with permission from Blackwell Publications). 
events has a profound influence on their ecology, because it determines the distribution and dispersal of aquatic biota and the exchange of energy and material. In this chapter, we describe headstream wetlands by attempting to harmonize the existing terminology derived mainly from larger river systems with the characteristics of riparian habitats along low-order streams. The three main criteria used for categorizing these wetlands are water permanency, exchange pathways of water and material, and substrate type.

\section{A. Hygropetric Zones}

A hygropetric zone is a thin layer of water covering a rock surface. It depends on the permanent recharge of the water film, which is usually generated from near-surface groundwater. Due to extremely shallow water depth, hygropetric zones provide ideal conditions for primary production, although UV light exposure and risk of drying provide harsh environmental conditions that limit the occurrence of macrobiota. Hygropetric zones are among the least studied habitats associated with tropical and temperate streams, although they can be expected to harbor many as yet undescribed species, particularly aquatic Lepidoptera, midges, and other Diptera (Fischer et al., 1998).

\section{B. Rock Pools}

Rock pools develop after floods recede along streams that flow over impermeable bedrock. The duration of water-logging depends on climatic conditions and size of the pool, but it can be extended by regular 'recharging' either by stream spates or by rain water. Rock pools can be considered as 'ecological batch experiments'. When first filled, the number of predators is low, and the presence of flood-borne organic matter and developing algal biomass makes rock pools favorable habitats for an array of invertebrates, such as chironomids (Diptera) and microcrustaceans (e.g. Jocque et al., 2006). Competition for resources in pools is initially low, but experiments in Amazonia have shown that there is fast development from individual-rich, species-poor assemblages to more diverse assemblages (Nolte, 1988, 1989), and the number of predators increases over time (Azevedo-Ramos and Magnusson, 1999). Specialized rockpool inhabitants have short life cycles and adaptations that allow them to survive droughts between filling phases. The chironomid genus Apedilum, for example, has an egg-to-egg life cycle duration of less than 1 week (Nolte, 1995). In the rock pools of a South American Cerrado stream, the mayfly Cloeodes hydation (Baetidae) can survive up to $9 \mathrm{~h}$ of desiccation and can even cope with drying/rehydration by reiterative moulting (Nolte et al., 1996). Rock pools along streams can be important breeding habitats for medically important dipteran vectors of human parasites such as malaria and elephantiasis.

\section{Para- and Orthofluvial Ponds}

In riparian floodplains, cut-and-fill alluviation, coupled with groundwater-surfacewater interactions, creates a complex array of shallow lentic habitats (ponds, backwaters, and abandoned channels). Ponds are either located in the active region (=parafluvial ponds) or in the adjacent riparian forest (=orthofluvial ponds). Often, floodplain ponds originate from 'abandoned' anabranching or anastomosing channels, formed by processes similar to those observed along large rivers (Wantzen et al., 2005b). During non-flood conditions, the exchange of water between ponds and the mainstream depends upon the presence of floodplain channels and the porosity of alluvium. In coarse-grained floodplains, for example, ponds are primarily fed by alluvial and hill-slope groundwaters. If the riparian zone is dominated by swamp forest, rotting tree roots or plant debris and decomposing organic matter lead to failures within the soil that 
can act as subterranean macropores delivering oxygen-rich stream water into floodplain ponds and water bodies (K. M. Wantzen, unpublished observations).

Aquatic organisms colonize para- and orthofluvial ponds from the permanent channel via porous interstitial flow paths through the stream hyporheic zone. The hyporheic zone may be extensive, and stream invertebrates have been found hundreds of metres from the channel of temperate rivers with coarse gravel floodplains (Stanford and Ward, 1988). In such situations, para- and orthofluvial ponds contribute disproportionately to aquatic biodiversity (Arscott et al., 2005). In tropical latitudes, similarly, high contribution of lateral habitats to total stream biodiversity can be anticipated. In sites where sediments are fine-grained, floodplain ponds tend to be more permanent or persistent, and are connected to the mainstream by secondary channels (i.e. direct connectivity) or via surface flow during flood events. Both the density and diversity of benthic invertebrates in Neotropical riparian forest ponds of Brazil are positively related to the degree of hydrological connectivity with mainstream but negatively correlated with leaf litter input (Wantzen et al., 2005a). The importance of riparian ponds can be inferred from the fact that Smock (1994) documented a net export of invertebrates from the floodplain to the main channel of streams in a subtropical forested wetland.

\section{Anabranches and Floodplain Channels}

In dynamic floodplain streams, and especially in braided sections, the flow becomes divided among several channels, comprising a main channel (transporting the largest portion of water) and numerable smaller anabranches. These channels, together with the floodplain channels that link the main channel with floodplain ponds (see Section II-C), offer habitat conditions that are generally similar to the main channel, although in seasonal tropical climates they may cease flowing during the drier months. In large river-floodplain systems, such as the Paraguay-Paraná system (see Wantzen et al., 2005b), flow in the floodplain channels and anabranches is sufficient to sustain rheophilic species in the riparian zone (e.g. Marchese et al., 2002). These habitats may also serve as refuges and potential sources for recolonization of the stream channel after major disturbances in temperate streams (Robinson et al., 2004). It is not known if the same phenomenon occurs in tropical streams, and analyses of the distribution of biota between the main channel and anabranches will be needed to resolve this.

\section{E. Moist Zones on the Riparian Floodplain}

Wetlands of this type are present along most unregulated streams. These comprise the zones fringing the stream channel that are wetted during spates or seasonal high-water periods, with expansion during flooding depending on the steepness of the stream channel and lateral slopes. The period for which surface-water is retained after a flooding event will vary according to the hydraulic conductivity of the substrate in the riparian zone: coarse sediments dry out within hours or a few days, while soils that are fine grained and well supplied with organic matter or stranded debris may maintain moisture long enough to allow aquatic or semi-aquatic insects such as tipulid and limoniid crane flies (Diptera) to complete their life cycles. Some terrestrial invertebrates inhabiting the floodplains of large tropical rivers have adaptations and strategies such as physical gills, anaerobiosis, and water-proof retreats, to survive wetted (and sometimes oxygen-free) periods, (Adis and Junk, 2002). Thus far, their counterparts living along tropical headwater streams have hardly been studied. The extent to which periodicallyinundated riparian zones along these streams serve as refugia for aquatic organisms during spates is not known, but passive drift or active migration into these low-flow marginal sites can take place. Moist riparian wetlands may also serve as refugia for upland terrestrial animals during droughts or seasonally dry periods. 
Small tropical rain forest streams receive considerable inputs of leaf litter (see Chapter 3); in Amazonia, this amounts to 6-10 tha $\mathrm{yr}^{-1}$ (Klinge, 1977; Adis et al., 1979; Luizão, 1982). Litter accumulates in banks on the inner side of lowland stream meanders. Litter banks extend from the riparian zone to the stream channel connecting the stream bed and the floodplain. Minor water-level fluctuations maintain humidity within litter accumulations, and steep oxygen gradients may build up. These banks provide microhabitats for stenotopic invertebrates and small fish species; dense and stable banks of litter may serve as refuges especially during floods (Walker, 1985). Feeding experiments with ${ }^{32} \mathrm{P}$-labeled leaves indicate that the animals inhabiting litter banks are sedentary and territorial (Walker et al., 1991; Walker and Henderson, 1998). Torrential flow conditions during intense spates disrupt litter banks, forcing the specialized litter-associated fauna to drift and colonize new accumulations downstream and exposing them to predation by open-water species during the 'reset mechanism' (Wantzen and Junk, 2006).

\section{F. Unforested Streamside Swamps}

These headwater wetlands are permanently moist due to low drainage, high precipitation, and/or shallow groundwater tables. The water-logged soils generally do not support woody vegetation. In seasonal savannah climates, such as those typical of the Brazilian Cerrado, these riparian wetlands are known as 'veredas' and extend $30-150 \mathrm{~m}$ from the stream edge. Veredas are characterized by grassy or graminoid vegetation and the presence of palms of the genus Mauritia. These support a rich array of plants and animals, but are extremely vulnerable to erosion (Wantzen et al., 2006, and citations therein). Similar wetlands can be found throughout the seasonal tropics on periodically moist, nutrient-poor soils; for example, in northern Madagascar and in the African Andropogon (Poaceae) savannah. 'Dambos', which is a Bantu word for seasonally wet, grass-covered, flat areas, forms characteristic water-logged wetlands that cover large areas of drainage basins in several parts of Africa (Balek and Perry, 1973; Acres et al., 1985). Almost 30\% of the Central Zambezi Miombo Woodland, one of the largest ecoregions in Africa, is occupied by dambos and other wetlands. Both perennial and non-perennial headwater swamps influence water resource availability in Africa because they act as reservoirs absorbing water during rainy season and releasing it during dry season. In addition, dambos are useful for agriculture and for grazing during dry season.

In the Upper Nile valley (e.g. along the major tributaries flowing into Lake Victoria), permanent swamps occupy areas of thousands of square kilometers. The vegetation consists of dense stands of grasses, reeds and sedges, such as Vossia cuspidate (Hippo grass), Phragmites, and Cyperus, and exotic water hyacinth (Eichhornia crassipes: Pontederiaceae). These are extremely productive habitats; the fresh biomass of Water hyacinth alone can exceed $70 \mathrm{~kg} \mathrm{~m}^{-2}$ (Denny, 1984).

\section{G. Forested Streamside Swamps}

The number of tree species adapted to long-term soil water logging along the streams is higher in the tropics than temperate regions. The vegetation associated with such conditions in savannahs is well described, because the riparian or gallery forest contrasts clearly with the surrounding grassland, and it is characteristically speciose (Felfili, 1995; Budke et al., 2004; see below). The demarcation of riverine forests from terrestrial forests is less clear, and floristic analyses of strictly riparian vegetation in the tropical forest regions are rare. In the Amazon Basin, researchers have differentiated the vegetation of large river floodplains from that of upland forests, but have not distinguished the composition of riparian forests along low-order streams from that of terrestrial forests.

Riparian trees are adapted to permanently saturated soils provide organic matter to the streams in the form of leaf litter, bark, etc.; these also act as a retention zone for drifting 
sediments and organic matter during spates. The chemical and physical recalcitrance of leaf litter produced can retard decomposition, reduce oxygen composition, and influence other aspects of soil and water conditions in these wetlands (see also Chapter 3). The tree canopies provide good shade so that these swamps experience less extreme microclimates than herbaceous or grassy wetlands; however, it can reduce the growth of algae and aquatic macrophytes (Fittkau, 1967). In dry or seasonal tropics, the wetland forest vegetation is highly dependent on groundwater, and the outer landward fringe tends to be more abrupt than in wetter areas. These narrow bands of forest facilitate animal migration along rivers, and their productivity exerts a major influence on adjacent drier and more terrestrial upland areas, making them a valuable natural resource (Hughes, 1988).

\section{H. Peatswamp Forests}

Peatswamp forests resemble forested streamside swamps, but have a completely different genesis, hydrology, and lateral extent. Unlike the wetlands described earlier, where the hydraulic forces of streams shape the riparian wetlands, peatswamps are primarily a product of plant succession on water-logged soils. These develop in areas of swamp forest where leaf litter and organic debris have accumulated in layers of peat that may reach $20 \mathrm{~m}$ in depth. For this reason, peatswamps are generally raised above nearby rivers, and the degree of interaction between these and rivers and wetlands may not be great, although they are hydrologically connected to them via numerous small streams draining the peat and flowing into larger rivers. Water is stored within peat accumulations in the wet season and released during the dry season, thus mitigating floods and droughts in the downstream parts of drainage. In low-lying coastal regions, peatswamps may develop behind mangrove swamps as the latter advance seawards on newly deposited alluvium. New plant communities develop on the land side, replacing the mangrove trees.

Southeast Asia presently covers the largest area of tropical peat lands in the world (Rieley and Page, 1997; Page et al., 2004), and peatswamp forests are the most extensive inland wetlands in Peninsular Malaysia and Borneo (particularly Sarawak and Kalimantan). Peatswamp forests also occur widely in the low-lying regions near large rivers in Sumatra, New Guinea, and Thailand. Peat in these swamp forests is largely composed of leaves and woody debris from trees (Anderson, 1964; Rieley and Page, 1997), and is thus quite different from peat occurring in bogs at higher latitudes that is built up mainly of Sphagnum moss, herbaceous plants, and grasses. Furthermore, most tropical peatswamp forests are relatively new, and have typically evolved within the past 4000 years following the last glacial maximum. Despite this, and their nutrient-poor soils, peatswamps can contain very many species of plants (Anderson, 1964; Rieley et al., 1997; see also below), including those that are endemic to these habitats, such as the commercially important tree Gonystylus bancanus (Thymelaceae) (Rieley et al., 1997; Dudgeon, 2000a, and references therein).

The difference between forested streamside swamps and peatswamps may not always be clear, but seems to be reflected in the classification of forested swamplands used by Rieley et al. (1997). They recognized topogenic and ombrogenous peatswamps. The former are riparian swamps that contain shallow accumulations of organic matter (much less than $50 \mathrm{~cm}$ ) that are flooded by rising water levels during wet season. These are equivalent to the forested streamside swamps described earlier. The latter are true peatswamps with thick ( $>50 \mathrm{~cm}$ up to $20 \mathrm{~m}$ ) accumulations of organic matter, which exist at some distance away from rivers and tend to be dome shaped or gently sloping. The domes of ombrogenous peatswamps are situated above the highest level of wet season flooding, but the water table is close to or above the surface for much of the year, and some of these peatswamps may be flooded for several months annually. Water drains outward from the center of the peatswamp dome in a series of streams that empty into rivers fringed with topogenic swamp forest. 
Regardless of the extent of seasonal inundation, conditions in the peatswamps and streams draining them may be quite extreme and, at the center of peatswamps in Asia, the forest may be dominated by few species - typically species in the dipterocarp genus Shorea (Rieley and Page, 1997). Dissolved oxygen and nutrient levels are low, the waters are acidic (typically $\mathrm{pH}$ 2.9-3.7) with limited autotrophic production, and high levels of tannins and other secondary compounds leached from plant litter typify these 'blackwaters'. The inhabitants are mostly stenotopic species that are tolerant to - or dependent upon - these conditions, and - as discussed below - include an array of fishes and invertebrates that are usually not found in other types of wetlands (Dudgeon, 2000a, 2000b; Ng et al., 1994; Ng, 2004).

\section{HYDROLOGY}

A natural inundation regime is regarded as the key driver of instream and riparian ecosystem processes and plays an important role in sustaining biodiversity (e.g. Junk et al., 1989; Poff et al., 1997; Junk and Wantzen, 2004). The magnitude, frequency, duration, and timing of the inundation regime influence biotic communities and ecosystem processes, either directly or indirectly, through their effects on other primary regulators, and modification of the inundation regime thus has cascading effects on the ecological integrity of river-floodplain systems (Bunn et al., 2005). Natural, unregulated streams exhibit two kinds of hydrologic behaviors with respect to increase in discharge: those that flood instream habitats within bankfull limits - i.e. 'flow-pulses' (sensu Tockner et al., 2000) - and those that spill over the bankfull limits and inundate the surrounding land - i.e. 'flood pulses' (sensu Junk et al., 1989; see also Junk and Wantzen, 2004). The 'flashiness' of the hydrograph depends on the size and topography of the catchment, on the precipitation regime, and on the hydrological buffering capacity of the riparian zone. The size of the area that may become flooded and the duration of flooding depend on the landscape gradient and obstacles that reduce the runoff in the channel. Steep valleys generally have intense, but brief, flood events, while plains and forested valleys have smaller, long-lasting floods. Often, spates can occur within moments of heavy rainstorm, which decrease over a few hours as rains abate. In areas that are either arid or have strong seasonal rainfall, stream discharge remains high relative to baseflow conditions (Fig. 2) as water percolates through the catchment into the channel (Poff et al., 1997; Bunn et al., 2005; Yoshimura et al., 2005).

It has been generally assumed that the correlation between the riparian zone and the stream channel during floods is insufficient time to permit consumers to exploit flood-borne resources, and that the unpredictability of individual spates would pose a risk of densityindependent mortality, limiting the potential of biota to become adapted to them (Junk et al., 1989). However, in tropical monsoonal regions or those with seasonal climate, the number of spates and the discharge volume in excess of baseflow increase predictably during rainy season (Wantzen and Junk, 2000; see Fig. 2). The gradual increase in flow leads to a progressive increase in the availability of riparian zone to aquatic fauna for several months in the year, resulting in greater habitat diversity. Larvae and juveniles of aquatic animals can escape from predation into permanently flooded habitats of the riparian zone, and many stream organisms benefit from flood-borne resources (see below).

Extended flooding in streams, lasting for several days or weeks, occurs during backflooding when the water level of the receiving river is so high that the discharge of tributary streams cannot enter and accumulate within these smaller channels. This phenomenon is common in streams draining the floodplains of large rivers (e.g. Rueda-Delgado et al., 2006) or streams that become blocked by sediments carried by rivers (Wantzen, 2003). Due to the impounding effect of sediment or water, the variation of current within streams is much lower during backfloods than during spates or flood events (Rueda-Delgado et al., 2006). 

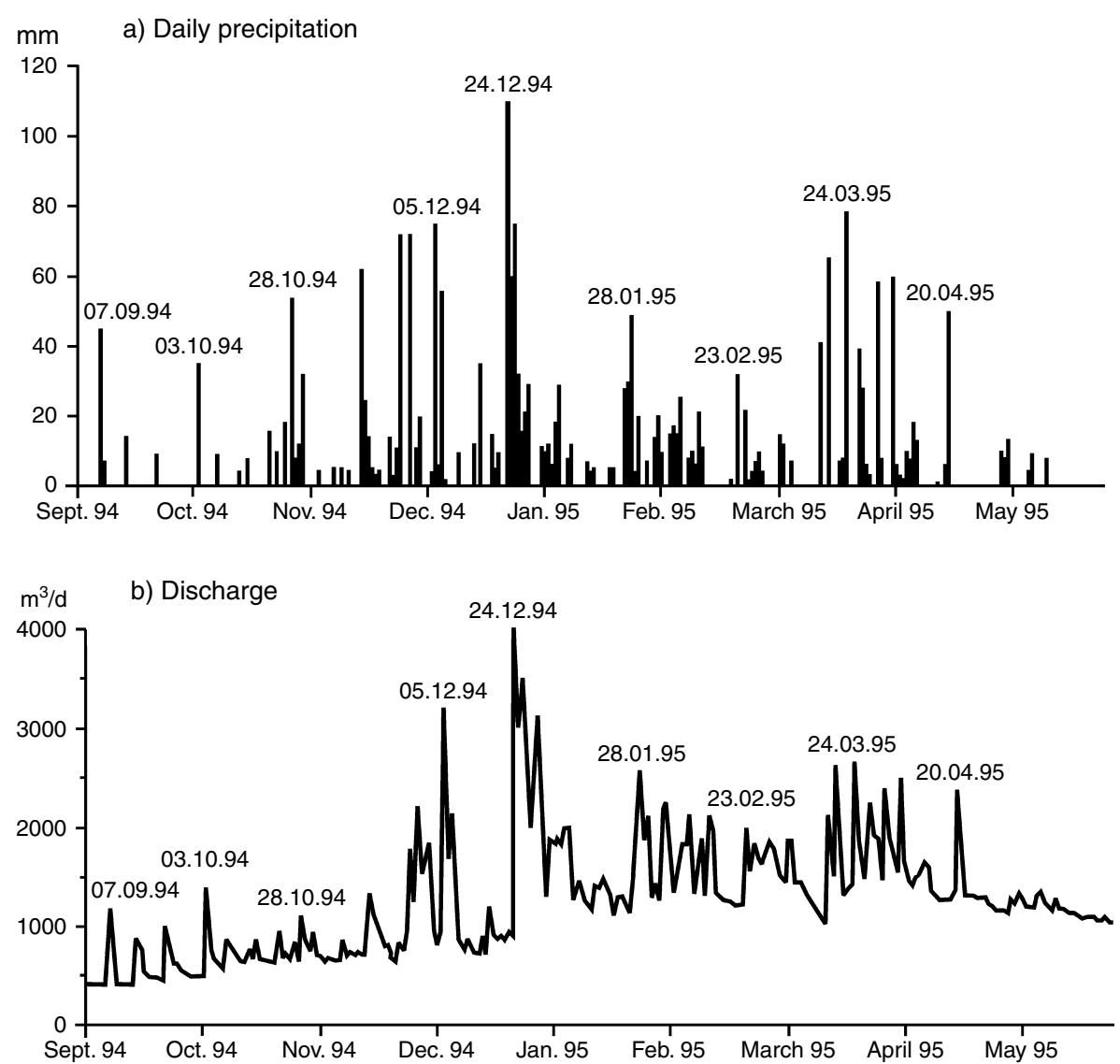

FIGURE 2 Precipitation and discharge of Tenente Amaral stream, a tributary of the São Lourenço River, Brazil (data from Wantzen, 2003).

In the seasonal tropics, intense rainfall can cause high surface runoff, which can lead to erosion, especially in small, low-order streams (e.g. Douglas, 1968). The mean annual maximum and minimum discharge ratio is a good indicator of the extent of flooding in riparian floodplains and of the strength of erosive forces. In northern Neotropics, this ratio is around 20 for rivers that drain savannah and dry forests, and below 10 for rivers that drain moist forests (Lewis et al., 1995; see also Chapter 1). Severe spates can remove or deliver particulate organic matter and reorganize the position of boulders and large woody debris, which in turn influence the flow velocity and patterns of erosion and deposition that affect channel architecture and may create new wetland patches (Edwards et al., 1999; Gurnell et al., 2005). Fine sediment deposits of the dry season that clog interstices between gravel and boulders become washed out during the first storms of the rainy season, which increases habitat diversity (Dudgeon, 1982). When floods recede, fine particles and significant quantities of organic matter (up to $1 \mathrm{~kg} \mathrm{DW} \mathrm{m}{ }^{2}$ : K. M. Wantzen, personal observations) become deposited among tree trunks and roots in the riparian zones and swamp forests, which may enhance soil formation. Alternate periods of wetting and drying in the riparian zones have important consequences on the dynamics of decomposition of such organic matter (Mathooko et al., 2000; see also Chapter 3). 


\section{BIODIVERSITY}

Although riparian wetlands are important for the biodiversity of aquatic and terrestrial species, our knowledge of the diversity of plant and animal species, as well as their specific adaptations to survive or to benefit from the wetting and drying cycle, is still scant (Wantzen and Junk, 2000). In most tropical areas, the species-effort-curves have yet to reach saturation, and the number of reported species tends to reflect sampling intensity. There is an urgent need to improve our taxonomic knowledge of riparian species and, given the rate of human modification of riparia (see below), there is increasing risk that many species may become extinct before even being described. The benthic stream fauna exhibit traits adapted to the hydraulic patterns that control substrate composition and oxygen supply (Statzner and Higler, 1986; Wagner and Schmidt, 2004). This applies also to the inhabitants of adjacent wetlands. Although substrate preferences vary among species, there is generally a positive relationship between substrate diversity, especially the presence of very coarse substrates, and species richness. The fringing wetlands not only represent an extension of stream habitats but can offer additional habitats with distinctive hydraulic and substrate conditions. The ecotonal nature of fringing riparian wetlands would lead to the supposition that they support much higher biodiversity than in permanent aquatic habitats or purely terrestrial habitats (Wantzen and Junk, 2000), including migratory species from both (Wantzen and Junk, 2006). Habitat dynamics in riparian ecotones are intermediate between the frequently disturbed conditions in the main stream channel and those in the more terrestrial portions, which are driven mainly by plant succession and periodic inundation/desiccation. Biodiversity in riparian wetlands is thus likely to be subject to the processes that tend to enhance diversity embodied in the intermediate-disturbance hypothesis (Ward et al., 2002).

When analyzing the real-world conditions, one finds that the expectation that biodiversity will peak in the riparian wetlands of tropical streams is not fulfilled by all taxonomic groups studied thus far. What factors may limit biodiversity in these wetlands? Some of the factors include, little or no water, high concentrations of dissolved organic matter leached from plant litter, and periodic scarcity or absence of oxygen. Studies on isolated wetland ponds in a swamp forest in Mato Grosso (Brazil) suggest that colonization by benthic invertebrates was inhibited by high levels of plant secondary compounds in water (Wantzen et al., 2005a), and similarly low colonization of seasonal pools in an Australian stream has been reported (Bunn, 1988). Acidic waters and lack of dissolved calcium limit the occurrence of decapod crustaceans and most mollusks in many tropical stream wetlands, e.g. Amazonia (Junk and Robertson, 1997) and Southeast Asian peatswamps (Ng et al., 1994; Dudgeon 2000a).

Despite apparently unfavorable conditions, some specialists do thrive. The water in streams that drain peatswamps is clear, but dark in colour due to dissolved phenolics, and is highly acidic $(\mathrm{pH} 2.5-4.5)$ and low in oxygen and nutrients. These habitats nonetheless support diverse, highly specialized and well-adapted endemic flora and fauna of global significance, as reported from peatswamp forests of Malaysia, Indonesia, and Thailand (Ng et al., 1994; Page et al., 1997; Ng, 2004). Fish biodiversity is especially high: $20 \%$ of the estimated 250 species of freshwater fishes in Peninsular Malaysia have been recorded from a single peatswamp, while the total number of fish species from such swamps in Malaysia, Borneo, and Sumatra is in the order of 200-300 (Ng, 2004). Over 200 plant species are known from the peatswamp forests of Peninsular Malaysia, while Anderson (1964) recorded 927 plant species from the peat swamp forests of Brunei and Sarawak (see also Rieley et al., 1997). Southeast Asian peat swamp forests are also home to an array of mammals, including primates and species of global conservation significance (Page et al., 1997; Dudgeon 2000a; see also Chapter 6). Because of the vast extent of plant and animal diversity that they support, Dudgeon (2000a) has proposed that swamp forests and peatswamps be treated as 'keystone habitats' of conservation priority in Asia. 
Plant biodiversity of riparian wetlands in seasonal Neotropics is very high. Felfili (1995) recorded 93 tree species in 81 genera and 44 families from 64 ha of undisturbed gallery forests in Brazilian Cerrado, while Budke et al. (2004) have identified 57 species in 47 genera and 26 families from 1 ha of riverine forest in subtropical southern Brazil. Samples from riparian vereda wetland in Minas Gerais (Brazil) hosted 136-361 species, in which as many as 168 were confined to this habitat type (Araújo et al., 2002). The invertebrate fauna of these ecotonal systems is still poorly known, although an exceptional diversity of copepod microcrustacean has been documented (Reid, 1984), but the composition and habitats of the stream-side and semi-aquatic mammals and most of the other vertebrates are not well known (see Chapter 6). Likewise, information on larger riparian animals in the Afrotropics is fragmentary (see Chapter 6 and references therein), but there have been some studies of dragonfly (Odonata) assemblages (Samways and Steytler, 1996) and the floristics of riparian forests (Natta et al., 2002) in Africa. More information on the composition and ecology of biodiversity in tropical stream wetlands is needed urgently, so that the population status of threatened species - especially those riparian obligates - can be assessed adequately and their habitat requirements better understood.

\section{AQUATIC-TERRESTRIAL LINKAGES}

Food webs in riparian wetlands are generally made up of short chains with a high degree of omnivory. Their structure is influenced by hydrology and usually depends on the maintenance of hydrological connectivity. Although these generalizations have been developed from research in the Australian wet-dry tropics (Douglas et al., 2005), these may apply generally for tropical streams and associated wetlands (see also Chapter 2).

As ecotones between the stream channel and upland, more terrestrial sites, riparian wetlands exhibit very steep ecological gradients, which are likely to enhance a variety of biological processes (Naiman, 1998). These include transfer of energy, nutrients, and material from the riparian zone to the stream (e.g. litter fall and resultant litter processing); transfer of energy, nutrients and material from the stream to surrounding terrestrial habitats (e.g. emergence of insects, predation upon adult aquatic insects); and production, storage, and processing of autochthonous biomass within the riparian wetland (Fig. 3). The intensity and timing of these

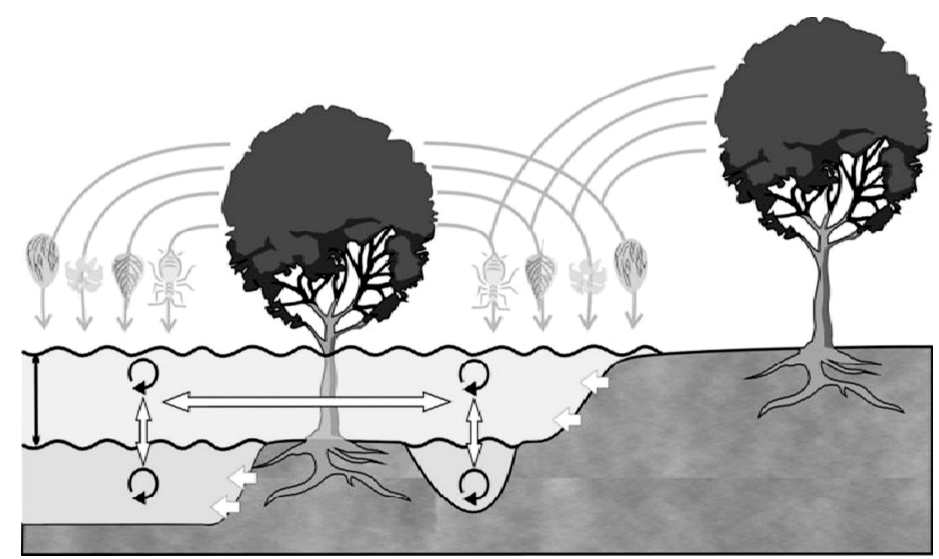

FIGURE 3 Wetland pools as 'bioreactors' for organic matter processing and temporary storage. During low water levels, wetland pools receive direct allochthonous inputs from trees (e.g. leaves, seeds, flowers, fallen insects), and they exchange this material with the stream during floods. Between floods, the relatively long residence time (compared with the stream channel) and ease of access by both aquatic and terrestrial consumers (during drying phases) enhance organic matter processing. 
processes may vary considerably, in part due to the variable nature and characteristics of riparian wetlands and also in response to stream hydrology. The frequency and extent of flooding are key factors in organic matter processing and exchange between main channel and floodplain, and in turn the relative contribution of organic matter derived from the catchment, the channel, and the floodplain, changes along the river course (Junk and Wantzen, 2004). Organic matter processing does not occur in an equilibrated time-space pattern, but rather at 'hot spots' and/or during 'hot moments' (sensu Wantzen and Junk, 2006). This temporal and spatial unpredictability challenges our ability to understand and quantify organic matter budgets in riparian wetlands.

Most riparian wetlands are highly productive, providing material and energy for adjacent ecosystems. The efficiency of the transfer rate of energy across the aquatic-terrestrial boundary depends on the ratio of shoreline length to stream area and the permeability of the boundary along the margins (Naiman et al., 1998). Flooding creates semi-aquatic conditions colonized by aquatic and terrestrial biota that benefit from the 'reciprocal subsidies' on the ecotone between the two bordering systems (Nakano and Murakami, 2001). For example, many terrestrial organisms depend on water-borne resources, such as flood wracks (Bastow et al., 2002) or emerging aquatic insects (Paetzold and Tockner, 2005), and both the stream channel and the riparian zone can be an important source of flying insects for terrestrial insectivores (Douglas et al., 2005). Conversely, aquatic consumers may move into newly inundated areas of riparian zones to feed, and fruits, seeds, and terrestrial insects can be important components of aquatic food webs (Nakano and Murakami, 2001). For example, $40 \%$ of the diet of freshwater crocodiles (Crocodylusa johnstoni: Crocodylidae) in Australia is of terrestrial origin, and terrestrial insects make seasonally variable contributions to the diet of tropical stream fishes (e.g. Chan and Dudgeon, 2006; see also Chapter 4).

Seasonal floods promote exchange between streams and their riparian zones, and facilitate reciprocal land-water subsidies, the most conspicuous of these being the transport of terrestrial (allochthonous) plant litter (see also Chapter 3). The residence time of such organic matter in riparian wetlands is intermediate to the stream channel and the adjacent terrestrial environment. As a result, pools associated with the riparian zone or floodplains of tropical streams are ideal 'bioreactor' habitats for the processing of terrestrial organic matter (see Chapter 3). For example, larvae of the trichopteran shredder Phylloicus (Calamoceratidae), which builds a case of dead leaves, occur in large numbers in the pools near Neotropical streams, where they shred litter that has been conditioned by microbes. Such larvae are uncommon in the mainstream leaf litter. Leaf litter turnover is high, and larvae and their food are likely to be transported downstream (Wantzen and Wagner, 2006).

With decreasing frequency of flooding, permanently wetted riparian wetland habitats tend to accumulate organic matter. This is most evident in tropical Asian peatswamp forests, where organic matter accumulates at the base of trees and forms hummocks. During rainy season, surface-water accumulates in depressions between the hummocks to create seasonally available open-water habitats for fishes and invertebrates. Other peatswamp forests may be more extensively inundated to some depth for months together, and these sites often have deep accumulations of peat (for details, see Rieley and Page, 1997). Decomposition of leaf litter is extremely slow in peatswamps because nutrient scarcity results in the production of leaves and other litter that are tough and toxic, and contain high levels of plant defensive compounds to deter terrestrial herbivores. Unpublished studies by C. Yule et al. suggest that accumulation of litter as peat takes place because it is not processed by microbes or aquatic invertebrates; however, in situ experiments indicate that aquatic bacteria and fungi are abundant in peatswamp streams and readily break down the leaves of less well-defended plants. These findings contradict the assumption (e.g. Whitmore, 1984) that peat builds up because of extreme conditions of acidity and low oxygen (see Chapter 3 for more details). The same authors also suggest that 
dissolved organic carbon from newly shed leaves is taken up by bacteria to provide the basis for a food web of invertebrate primary consumers and their predators.

\section{HUMAN IMPACTS, CONSERVATION, AND SUSTAINABLE MANAGEMENT}

Removal of riparian vegetation may alter the morphology of stream and river channels and the ecosystem services (Sweeney et al., 2004). Unfortunately, conservation of riparian wetlands is hampered by the fact that they are often ephemeral, and thus their importance may not be evident during baseflow conditions. Even permanent riparian wetlands generally occupy only narrow strips adjacent to the channel of low-order streams, and thus they are inconspicuous despite the fact, as discussed earlier (see Table I), that their combined area within a catchment may be substantial (e.g. Wantzen et al., 2006). Such wetlands are perceived by humans as favorable sites for colonization, agriculture, or pasture. The factors that make these systems biologically productive and diverse also make them attractive to humans and subject to anthropogenic alteration of stream environments and land-use changes in the surrounding drainage basin. The latter include cattle trampling and more general impacts arising from land-use changes and deforestation, which release large amounts of sediments and can lower the groundwater table in wetlands (Wantzen, 2006; K. M. Wantzen et al., unpublished observations). Proximity to water will facilitate the construction of aquaculture enterprises in streamside wetlands, with the associated risk of releasing exotic fishes and crustaceans into the environment (Orsi and Agostinho, 1999; other examples are given in Chapter 3).

Channel rectification and channel deepening of streams have destroyed most riparian wetlands along headwater streams in agricultural and urban landscapes, and they are often subject to water extraction or impoundments for irrigation (see Chapter 10 for details of other threats to tropical streams). The increasing use of small-scale dams for hydropower is a particular threat for low-order streams; here, a solution could be to 'sacrifice' certain streams and to maintain the natural hydrological dynamics and longitudinal connectivity of some portion of each drainage basin or stream of particular ecological importance (Greathouse et al., 2006). Virtually all human activities in the riparian wetlands reduce the area, amplitude, and frequency of flood events, which are precisely the conditions needed to sustain wetlands (Richter et al., 1996). Changes in hydrological regime are not only deleterious for the native biota of streams and their wetlands, but they favor the distribution of exotic plants (Bunn and Arthington, 2002; see also Chapter 10).

Of all the riparian wetlands along tropical streams, the threats to tropical peatswamp forest are of particular concern, and this is one of most threatened wetland habitat types of the world (Dudgeon, 2000a; Ng et al., 1994). For instance, by the year, 2000, 77\% of the peat swamp forests of Peninsular Malaysia had been cleared of the remainder, only half is considered to be in pristine condition (Mohamed Idris, 2001), and much of the rest - as well as huge swathes in Kalimantan - are scheduled for logging or conversion to agriculture (especially oil palm). These wetlands have all but disappeared from Java (Whitten et al., 1997). The conversion of peatswamp forests for agriculture is generally difficult and expensive, and often takes place after the forest has been burned. The resulting soils are acidic, low in nutrients and bulk density, hydrophobic, and subject to subsidence (Notohadiprawiro, 1996), and many areas that were drained and cleared have become unproductive wasteland. Draining and selective logging of peatswamps increases the frequency of fires. In 1994, 1997, and 2002, ENSO-related drought events combined with peat forest clearing and draining resulted in widespread, devastating fires across Borneo, Sumatra, and Irian Jaya, which released enormous amounts of carbon into the atmosphere, contributing to global warming (Page et al., 2002).

Conservation and restoration schemes for riparian wetlands along all streams and rivers depend on the maintenance or re-establishment of hydrological diversity and landscape 
dynamism within drainage basins (Ward et al., 1999; Zalewski et al., 2001; Wantzen and Junk, 2004; Douglas et al., 2005). This is especially difficult in tropical latitudes inhabited by large human populations with reasonable expectations of socioeconomic development and livelihood improvements, in a context where environmental legislation is often lacking or weakly enforced (Dudgeon et al., 2000), and financial support for conservation initiatives is poor. On priority is the need to communicate the economic values of functioning riparian wetlands (e.g. Sweeney et al., 2004; Naiman et al., 2005) so as to help raise awareness among policy makers. These values include buffering hydrological variability and maintenance of continuous spring flows or stream discharge during low-flow periods; amelioration of regional climatic fluctuations, and carbon sequestration/storage; storage and sequestration of agrochemicals and heavy metals; soil protection and control of erosion; maintenance of biodiversity through habitat provision; and provision of goods of economic and subsistence importance, such as fish, timber, and forest products (e.g. fruits, resins, and medicinal plants).

The indirect economic value of the functions provided by tropical riparian wetlands is difficult to assess, although it is an issue that needs to be addressed with some urgency. One global benefit of increasing importance is storage and sequestration of carbon, especially in peatswamps (Page et al., 2004). Parish (2002) estimated that a 10-m-deep layer of tropical peat stores $5800 \mathrm{t} \mathrm{C} \mathrm{ha}^{-1}$, as compared with $300-500 \mathrm{t} \mathrm{ha}^{-1}$ for other tropical forests. For this reason the destruction of Asian peatswamps is a matter of global concern as conversion for agriculture may result in rapid decomposition of peat and liberation of stored carbon. While the amounts of carbon that might be released are not known with certainty, it is evident that soils that are high in organic matter have the highest rates of carbon loss (Bellamy et al., 2005). Similarly, high carbon storage and potential losses can be anticipated in other riparian wetlands, such as the Neotropical Cerrado of Mato Grosso (K.M. Wantzen et al., unpublished observations).

While global carbon emissions are gaining increasing global attention, small-scale or local conservation schemes that yield immediate economic returns for stakeholders are needed to protect riparian headwater wetlands. This can be best achieved by the combination of law enforcement and involvement of local communities with the resources they depend upon. For instance, Wantzen et al. (2006) have suggested that planting buffer zones of native trees between the agricultural areas and riparian wetlands in the Brazilian Cerrado might reduce the degradation of streamside habitat. The commercial use of non-wood products from the trees would help offset the costs of planting, and provide an additional income to the farmers. This system could also be used to restore or enhance the existing erosion gullies caused by streamside agriculture. Care must be taken: such schemes do not offer 'one size fits all', which can be applied across a region (certainly not across the tropics as a whole), and the outcome of projects intended to enhance riparian ecotones is bound to depend on the current state of alteration or degradation of the system. Particular attention needs to be paid to the use of appropriate approaches and technologies for a given region, including the use of native species for re-vegetation and habitat restoration.

\section{CONCLUSIONS AND PROSPECTS}

Riparian wetlands associated with tropical headwater streams fulfill an important and essential ecosystem functions, yet they are severely endangered by a range of non-sustainable and, perhaps, irreversible human activities. Conservationists and landscape managers in the tropics face the challenge that detailed studies are needed to better understand the functions and values of riparian wetlands while, at the same time, the rate of degradation and habitat alterations continues to increase and requires immediate action (Moulton and Wantzen, 2006; see also Chapter 10). While this review does not allow us to take a prescriptive stance upon 
the additional research that will be needed to facilitate decision-making, some lacunae in our knowledge have became evident during its preparation. For example, it became apparent that we are less informed about floodplains in Africa and Asia, and future research should include these areas. However, even within a given region, our knowledge of different wetland types was fragmentary, and we lack the complete picture of these ecotones for any part of the tropics. Some other conspicuous and potentially-important information gaps are set out below, and indicate some research priorities for stream ecologists and colleagues from cognate disciplines.

- Where and when do geochemical and biotic 'hot spots' and 'hot moments' occur in riparian wetlands? What are the locations and periods of significant nutrient inputs and organic matter turnover?

- How and when are riparian wetlands colonized? Which are the organisms that depend upon them as a migration corridor?

- What are the interactions between terrestrial and aquatic organisms within riparian wetlands? To what extent there is 'reciprocity' in the transfer of energy and material between land and water, and how is it mediated by trophic interactions in ecotones?

- Which life stages are dependent on particular habitats within land-water ecotones along headwater streams? How does connectivity across the ecotone or along stream networks influence biodiversity in tropical riparian wetlands?

- How do aquatic and terrestrial invertebrates as well as fishes adapt to, exploit, or tolerate with periodic flooding or desiccation of the riparian zone? To what extent do these strategies make them vulnerable to anthropogenic modification of seasonal flow regimes?

\section{REFERENCES}

Acres, B.D., Blair Rains, A., King, R.B., Lawton, R.M., Michell, A.J.B., and Rackham, L.J. (1985). African dambos: their distribution, characteristics and use. Zeitschrift für Geomorphologie N.F., Supplement 52, 63-86.

Adis, J., and Junk, W.J. (2002). Terrestrial invertebrates inhabiting lowland river floodplains of Central Amazonia and Central Europe: a review. Freshwater Biology 47, 711-731.

Adis, J., Furch, K., and Irmler, U. (1979). Litter production of a Central Amazonian inundation forest. Tropical Ecology 20, 236-245.

Anderson, J.A.R. (1964). The structure and development of the peatswamps of Sarawak and Brunei. Journal of Tropical Geography 18, 7-16.

Araújo, G.M., Barbosa, A.A.A., Arantes, A.A., and Amaral, A.F. (2002). Composição florística de veredas no Município de Uberlândia, MG. Revista Brasileira de Botânica 25, 475-493.

Arscott, D.B., Tockner, K., and Ward, J.V. (2005). Lateral organization of aquatic invertebrates along the corridor of a braided floodplain river. Journal of the North American Benthological Society 24, 934-954.

Azevedo-Ramos, C., and Magnusson, W.E. (1999). Predation as the key factor structuring tadpole assemblages in a savanna area in Central Amazonia. Copeia 1, 33.

Balek, J., and Perry, J.E. (1973). Hydrology of seasonally inundated African headwater swamps. Journal of Hydrology $19,227-249$.

Bastow, J.L., Sabo, J.L.M., Finlay, J.C., and Power, M.E. (2002). A basal aquatic-terrestrial trophic link in rivers: algal subsidies via shore-dwelling grasshoppers. Oecologia 131, 261-268.

Bellamy, P.H., Loveland, P.J., Bradley, R.I., Lark, R.M., and Kirk, G.J.D. (2005). Carbon losses from all soils across England and Wales, 1978-2003. Nature 437, 245-248.

Brinson, M.M. (1993). Changes in the functioning of wetlands along environmental gradients. Wetlands 13, 65-74.

Budke, J.C., Giehl, E.L.H., Athayde, E.A., Eisinger, S.M., and Záchia, R.A. (2004). Florística e fitossociologia do componente arbóreo de uma floresta ribeirinha, arroio Passo das Tropas, Santa Maria, RS, Brasil. Acta Botânica Brasileira 18, 581-589.

Bunn, S.E. (1988). Processing of leaf litter in two northern Jarrah Forest streams, Western Australia: II. The role of macroinvertebrates and the influence of soluble polyphenols and inorganic sediment. Hydrobiologia 162, 211-223. 
Bunn, S.E., and Arthington, A.H. (2002). Basic principles and ecological consequences of altered flow regimes for aquatic biodiversity. Environmental Management 30, 492-507.

Bunn, S.E., Thoms, M.C., Hamilton, S.K., and Capon, S.J. (2005). Flow variability in dryland rivers: boom, bust and the bits in between. River Research and Applications 22, 179-186.

Chan, E.K.W., and Dudgeon, D. (2006). Riparian vegetation affects the food supply of stream fish in Hong Kong. In "Sustainable Management of Protected Areas for Future Generations" (C.Y. Jim and R.T. Corlett, Eds), pp. 219-231. World Conservation Union (IUCN) and World Commission on Protected Areas (WPCA), Gland, Switzerland.

Denny, P. (1984). Permanent swamp vegetation of the Upper Nile. Hydrobiologia 110, 79-90.

Douglas, I. (1968). Erosion in the Sungai Gombak catchment, Selangor, Malaysia. Journal of Tropical Geography 26, $1-16$.

Douglas, M.M., Bunn, S.E., and Davies, P.M. (2005). River and wetland food webs in Australia's wet-dry tropics: general principles and implications for management. Marine and Freshwater Research 56, 329-342.

Dudgeon, D. (1982). Spatial and temporal changes in the sediment characteristics of Tai Po Kau Forest Stream, New Territories, Hong Kong, with some preliminary observations upon within-reach variations in current velocity. Archiv für Hydrobiologie, Supplement 64, 36-64.

Dudgeon, D. (2000a). Riverine wetlands and biodiversity conservation in tropical Asia. In "Biodiversity of Wetlands: Assessment, Function and Conservation, Vol. 1” (B. Gopal, W.J. Junk and J.A. Davis, Eds), pp. 35-60. Backhuys Publishers, Leiden, The Netherlands.

Dudgeon, D. (2000b). The ecology of tropical Asian rivers and streams in relation to biodiversity conservation. Annual Review in Ecology and Systematics 31, 239-263.

Dudgeon, D., Choowaew, S., and Ho, S.-C. (2000). River conservation in South-east Asia. In "Global Perspectives on River Conservation: Science, Policy and Practice” (P.J. Boon, B.R. Davies and G.E. Petts, Eds.), pp. 281-310. John Wiley and Sons, Chichester, UK.

Edwards, P.J., Kollmann, J., Gurnell, A.M., Petts, G.E., Tockner, K., and Ward, J.V. (1999). A conceptual model of vegetation dynamics on gravel bars of a large Alpine river. Wetlands Ecology and Management 7, 141-153.

Felfili, J.M. (1995). Diversity, structure and dynamics of a gallery forest in central Brazil. Vegetatio 117, 1-15.

Fischer, J., Fischer, F., Schnabel, S., Wagner, R., and Bohle, H.W. (1998). The biology of springs and springbrooks. In "Studies in Crenobiology" (L. Botosaneanu, Ed.), pp. 181-199. Backhuys Publishers, Leiden, The Netherlands.

Fittkau, E.J. (1967). On the ecology of Amazonian rain-forest streams. In "Atas do Simpósio sôbre a Biota Amazônica, Vol. 3 (Limnologia)” (H. Lent, Ed.), pp. 97-108. Rio de Janeiro: Conselho Nacional des Pesquisas, Rio de Janeiro, Brazil.

Greathouse, E.A., Pringle, C., and Holmquist, J.E. (2006). Conservation and management of migratory fauna: dams in tropical streams of Puerto Rico. Aquatic Conservation 16, 695-712.

Gurnell, A.M., Tockner, K., Edwards, P.J., and Petts, G. (2005). Effects of deposited wood on biocomplexity of river corridors. Frontiers in Ecology and Environment 3, 377-382.

Harner, M.J., and Stanford, J.A. (2003). Differences in cottonwood growth between a losing and a gaining reach of an alluvial floodplain. Ecology 84, 1453-1458.

Hughes, F.M.R. (1988). The ecology of African floodplain forests in semi-arid and arid zones: a review. Journal of Biogeography 15, 127-140.

Jocque, M., Martens, K., Riddoch, B., and Brendonck, L. (2006). Faunistics of ephemeral rock pools in southeastern Botswana. Archiv für Hydrobiologie 165, 415-431.

Junk, W.J., and Robertson, B.A. (1997). Aquatic invertebrates. In "The Central Amazon Floodplain - Ecology of a Pulsing System” (W.J. Junk, Ed.), pp. 279-298. Springer Verlag GMbH, Berlin.

Junk, W.J., and Wantzen, K.M. (2004). The flood pulse concept. New aspects, approaches, and applications - an update. In "Proceedings of the 2nd Large River Symposium (LARS), Phnom Penh, Cambodia" (R. Welcomme and T. Petr, Eds), pp. 117-149. Food and Agriculture Organization and Mekong River Commission, RAP Publication, 2004/16, Bangkok, Thailand.

Junk, W.J., Bayley, P.B., and Sparks, R.E. (1989). The Flood Pulse Concept in river-floodplain-systems. Canadian Special Publication of Fisheries and Aquatic Sciences 106, 110-127.

Klinge, H. (1977). Fine litter production and nutrient return to the soil in three natural forest stands of Eastern Amazonia. Geology and Ecology of the Tropics 1, 159-167.

Lewis, W.M., Jr, Hamilton, S.K., and Saunders, J.F., III (1995). Rivers of Northern South America. In "River and Stream Ecosystems" (C.E. Cushing, K.W. Cummins and G.W. Minshall, Eds), pp. 219-256. Elsevier, Amsterdam, The Netherlands.

Luizão, F. (1982). "Produção e Decomposição de Liteira em Floresta de Terra Firme da Amazônia Central. Aspectos Químicos e Biológicos da Llixiviação e Remorção de Nutrientes da Liteira”. Unpuplished MSc. Thesis, FUA/INPA, Manaus, Brazil.

Marchese, M.R., Escurra de Drago, I., and Drago, E.C. (2002). Benthic macroinvertebrates and physical habitat relationships in the Paraná River-floodplain system. In "The Ecohydrology of South American Rivers and Wetlands" (M.E. McClain, Ed.), pp. 111-132. International Association of Hydrological Sciences, Wallingford, UK. 
Mathooko, J.M., M'Erimba, C.M., and Leichtfried, M. (2000). Decomposition of leaf litter of Dombeya goetzenii in the Njoro River, Kenya. Hydrobiologia 418, 147-152.

McClain, M.E., and Elsenbeer, H. (2001). Terrestrial inputs to Amazon streams and internal biogeochemical processing. In "The Biogeochemistry of the Amazon Basin" (M.E. McClain, R.L. Victoria and J.E. Richey, Eds.), pp 185-208. Oxford University Press, New York.

McClain, M.E., Richey, J.E., and Pimentel, T.P. (1994). Groundwater nitrogen dynamics at the terrestrial-lotic interface of a small catchment in the Central Amazon Basin. Biogeochemistry 27, 113-127.

McClain, M.E., Boyer, E.W., Dent, C.L., Gergel, S.E., Grimm, N.B., Groffman, P., Hart, S.C., Harvey, J., Johnston, C., Mayorga, E., Mcdowell, W.H., and Pinay, G. (2003). Biogeochemical hot spots and hot moments at the interface of terrestrial and aquatic ecosystems. Ecosystems 6, 301-312.

McCormick, J.F. (1979). A summary of the national riparian symposium. In "Strategies for Protection and Management of Floodplain Wetlands and other Riparian Ecosystems” (R.R. Johnson and J.F. McCormick, Eds), pp. 362363. United States Department of Agriculture, Forest Service (General Technical Report WO 0197-6109: 12), Washington, DC, USA.

Mohamed Idris, S.M. (2001). “Malaysian Environment Alert, 2001”. Sahabat Alam Malaysi, Pulau Pinang, Malaysia.

Moulton, T., and Wantzen, K.M. (2006). Conservation of tropical streams - special questions or conventional paradigms? Aquatic Conservation 16, 659-663.

Naiman, R.J. (1988). Animal influences on ecosystem dynamics. Bioscience 38, 750-752.

Naiman, R.H., Décamps, H., Pastor, J., and Johnston, C.A. (1988). The potential importance of boundaries to fluvial systems. Journal of the North American Benthological Society 7, 289-306.

Naiman, R.J., Décamps, H., and McClain, M.E. (2005). "Riparia: Ecology, Conservation, and Management of Streamside Communities". Elsevier, New York.

Nakano, S., and Murakami, M. (2001). Reciprocal subsidies. Dynamic interdependence between terrestrial and aquatic food webs. Proceedings of the National Academy of Sciences 98, 166-170.

Natta, A.K., Sinsin, B., and Van der Maesen, L. (2002). Riparian forests, a unique but endangered ecosystem in Benin. Botanische Jahrbuecher fuer Systematik, Pflanzengeschichte und Pflanzengeographie 55, 55-69.

Ng, P.K.L. (2004). A tragedy with many players. Nature 430, 396-398.

Ng, P.K.L., Tay, J.B., and Lim, K.K.P. (1994). Diversity and conservation of blackwater fishes in Peninsular Malaysia, particularly the North Selangor peat swamp forest. Hydrobiologia 285, 203-218.

Nolte, U. (1988). Small water colonization in pulse stable varzea and constant terra firme biotopes on the Neotropics. Archiv für Hydrobiologie 113, 541-550.

Nolte, U. (1989). Observations on Neotropical rainpools with emphasis on Chironomidae (Diptera). Studies on Neotropical Fauna and Environment 24, 105-120.

Nolte, U. (1995). From egg to imago in less than seven days, Apedilum eachistum (Chironomidae). In "Chironomids: from Genes to Ecosystems” (P.S. Cranston, Ed.), pp. 177-184. CSIRO Publications, Melbourne, Australia.

Nolte, U., Tietböhl, R.S., and McCafferty, W.P. (1996). A mayfly from tropical Brazil capable of tolerating short-term dehydration. Journal of the North American Benthological Society 15, 87-94.

Notohadiprawiro, T. (1996). Constraints to achieving the agricultural potential of tropical peatlands - an Indonesian perspective. In "Tropical Lowland Peatlands of Southeast Asia. Proceedings of a Workshop on Integrated Planning and Management of Tropical Lowland Peatlands held at Cisarua, Indonesia, 3-8 July, 1992” (E. Maltby, C.P. Immirzi and R.J. Safford, Eds), pp. 139-154. IUCN, Gland, Switzerland.

Orsi, M.L., and Agostinho, A.A. (1999). Introdução de espécies de peixes por escapes acidentais de tanques de cultivo em rios da bacia do Rio Paraná, Brasil. Revista Brasileira de Zoologia 16, 557-560.

Paetzold, A., and Tockner, K. (2005). Effects of riparian arthropod predation on the biomass and abundance of aquatic insect emergence. Journal of the North American Benthological Society 24, 395-402.

Page, S.E., Rieley, J.O., Doody, K., Hodgson, S., Husson, S., Jenkins, P., Murrough-Bernard, H., Otway, S., and Wilshaw, S. (1997). Biodiversity of tropical peatswamp forest: a case study of animal diversity in the Sungai Sebangau catchment of Central Kalimantan, Indonesia. In "Tropical Peatlands” (J.O. Rieley and S.E. Page, Eds), pp. 231-242. Samara Publishing Ltd., Cardigan, UK.

Page, S.E., Siegert, F., Rieley, J.O., Boehm, H.-D., Jaya, A., and Limin, S. (2002). The amount of carbon released from peat and forest fires in Indonesia during, 1997. Nature 420, 6165.

Page, S.E., Wust, R.A.J., Weiss, D., Rieley, J.O., Shotyk, W., and Limin, S.H. (2004). A record of Late Pleistocene and Holocene carbon accumulation and climate change from an equatorial peat bog (Kalimantan, Indonesia): implications for past, present and future carbon dynamics. Journal of Quaternary Sciences 19, 625-635.

Parish, F. (2002). Overview on peat, biodiversity, climate change and fire. In "Prevention and Control of Fire in Peatlands. Proceedings of the Workshop on Prevention and Control of Fire in Peatlands, 19-21 March, 2002, Kuala Lumpur” (F. Parish, E.C. Padmanabhan, L. Lee and H.C. Thang, Eds), pp. 320-331. Global Environment Centre and Forestry Department, Kuala Lumpur, Malaysia.

Poff, N.L., Allan, J.D., Bain, M.B., Karr, J.R., Prestegaard, K.L., Richter, B.D., Sparks, R.E., and Stromberg, J.C. (1997). The natural flow regime - a paradigm for river conservation and restoration. Bioscience 47, 769-784. 
Reid, J.W. (1984). Semiterrestrial meiofauna inhabiting a wet campo in Central Brasil, with special reference to the Copepoda (Crustacea). Hydrobiologia 118, 95-111.

Richter, B.D., Baumgartner, J.V., Powell, J., and Braun, D.P. (1996). A method for assessing hydrologic alteration within ecosystems. Conservation Biology 10, 1163-1174.

Rieley, J.O., and Page, S.E. (Eds) (1997). “Tropical Peatlands”. Samara Publishing Ltd., Cardigan, UK.

Rieley, J.O., Page, S.E., Limin, S.H., and Winarti, S. (1997). The peatland resource of Indonesia and the Kalimantan Peat Swamp Forest Research Project. In "Tropical Peatlands" (J.O. Rieley and S.E. Page, Eds), pp. 37-44. Samara Publishing Ltd., Cardigan, UK.

Robinson, C.T., Tockner, K., and Burgherr, P. (2004). Drift benthos relationships in the seasonal colonization dynamics of alpine streams. Archiv für Hydrobiologie 160, 447-470.

Rueda-Delgado, G., Wantzen, K.M., and Beltrán, M. (2006). Leaf litter decomposition in an Amazonian floodplain stream: impacts of seasonal hydrological changes. Journal of the North American Benthological Society 25, 231-247.

Samways, M.J., and Steytler, N.S. (1996). Dragonfly (Odonata) distribution patterns in urban and forest landscapes, and recommendations for riparian management. Biological Conservation 78, 279-288.

Smock, L.A. (1994). Movements of invertebrates between stream channels and forested floodplains. Journal of the North American Benthological Society 13, 524-531.

Stanford, J.A., and Ward, J.V. (1988). The hyporheic habitat of river ecosystems. Nature 335, 64-66.

Statzner, B., and Higler, B. (1986). Stream hydraulics as a major determinant of benthic invertebrate zonation patterns. Freshwater Biology 16, 127-139.

Sweeney, B.W., Bott, T.L., Jackson, J.K., Kaplan, L.A., Newbold, J.D., Standley, L.J., Hession, W.C., and Horwitz, R.J. (2004). Riparian deforestation, stream narrowing, and loss of stream ecosystem services. Proceedings of the National Academy of Sciences 101, 14132-14137.

Tiner, R.W. (1999). "Wetland Indicators. A Guide to Wetland Identification, Delineation, Classification, and Mapping”. Lewis Publishers, Boca Raton, USA.

Tockner, K., and Stanford, J.A. (2002). Riverine flood plains. present state and future trends. Environmental Conservation $29,308-330$.

Tockner, K., Malard, F., and Ward, J.V. (2000). An extension of the Flood Pulse Concept. Hydrological Processes 14, 2861-2883.

Wagner, R., and Schmidt, H.-H. (2004). Yearly discharge patterns determine species abundance and community diversity: analysis of a 25 year record from the Breitenbach. Archiv für Hydrobiologie 16, 511-540.

Walker, I. (1985). On the structure and ecology of the micro-fauna in the Central Amazonian forest stream Igarapé da Cachoeira. Hydrobiologia 122, 137-152.

Walker, I., and Henderson, P.A. (1998). Ecophysiological aspects of Amazonian blackwater litterbank fish communities. In "Physiology and Biochemistry of Fishes of the Amazon" (A.L. Val, V.M.F. Almeida-Val and D.J. Randall, Eds), pp. 7-22. INPA, Manaus, Brazil.

Walker, I., Henderson, P.A., and Sterry, P. (1991). On the patterns of biomass transfer in the benthic fauna of an amazonian black-water river, as evidenced by ${ }^{32} \mathrm{P}$ label experiment. Hydrobiologia 215, 153-162.

Wantzen, K.M. (2003). Cerrado streams - characteristics of a threatened freshwater ecosystem type on the tertiary shields of South America. Amazoniana 17, 485-502.

Wantzen, K.M. (2006). Physical pollution: effects of gully erosion in a tropical clear-water stream. Aquatic Conservation 16 (7), 733-749.

Wantzen, K.M., and Junk, W.J. (2000). The importance of stream-wetland-systems for biodiversity: a tropical perspective. In "Biodiversity of Wetlands: Assessment, Function and Conservation, Vol. 1" (B. Gopal, W.J. Junk and J.A. Davis, Eds), pp. 311-334. Backhuys Publishers, Leiden, The Netherlands.

Wantzen, K.M., and Junk, W.J. (2006). Aquatic-terrestrial linkages from streams to rivers: biotic hot spots and hot moments. Archiv für Hydrobiologie Supplement 158, 595-611.

Wantzen, K.M., and Junk, W.J. (2008). Riparian wetlands. In "Encyclopaedia of Ecology” (B. Ronan, Ed.), in press. Elsevier, New York.

Wantzen, K.M., and Wagner, R. (2006). Detritus processing by shredders: a tropical-temperate comparison. Journal of the North American Benthological Society 25, 214-230.

Wantzen, K.M., Da Rosa, F.R., Neves, C.O., and Nunes Da Cunha, C. (2005a). Leaf litter addition experiments in riparian ponds with different connectivity to a Cerrado Stream in Mato Grosso, Brazil. Amazoniana 18, 387-396.

Wantzen, K.M., Drago, E., and da Silva, C.J. (2005b). Aquatic habitats of the Upper Paraguay River-Floodplain-System and parts of the Pantanal (Brazil). Ecohydrology and Hydrobiology 21, 1-15.

Wantzen, K.M., Sá, M.F.P., Siqueira, A., and Nunes da Cunha, C. (2006). Conservation scheme for forest-streamecosystems of the Brazilian Cerrado and similar biomes in the seasonal tropics. Aquatic Conservation 16, 713-732.

Ward, J.V., Tockner, K., and Schiemer, F. (1999). Biodiversity of floodplain river ecosystems: ecotones and connectivity. Regulated Rivers: Research and Management 15, 125-139.

Ward, J.V., Tockner, K., Arscott, D.B., and Claret, C. (2002). Riverine landscape diversity. Freshwater Biology 47, 517-539. 
Whitmore, T.C. (1984). “Tropical Rainforests of the Far East. 2nd Edition”. Clarendon Press, Oxford, UK.

Whitten, T., Soeiaatmajda, R.E., and Afiff, S.A. (1997) “The Ecology of Java and Bali”. Oxford University Press, Oxford.

Yoshimura, C., Omura, T., Furumai, H., and Tockner, K. (2005). Present state of rivers and streams in Japan. River Research and Applications 21, 93-112.

Zalewski, M., Bis, B., Frankiewicz, P., Lapinska, M., and Puchalski, W. (2001). Riparian ecotone as a key factor for stream restoration. Ecohydrology and Hydrobiology 1, 245-251. 